\title{
THE INTEGRATING ECOLOGICAL URBAN ENVIRONMENTAL PERFORMANCE CRITERIA IN URBAN DESIGN STUDIOUS OF UNIVERSITY STUDENTS
}

\author{
Çiğdem Çiftçi ${ }^{*}$, Fatma Kunt ${ }^{2}$ \\ ${ }^{1 *}$ Necmettin Erbakan University, Faculty of Engineering and Architecture, Department of Urban and Regional \\ Planning, Konya, Turkey; \\ ${ }^{2}$ Necmettin Erbakan University, Faculty of Engineering and Architecture, Department of Environmental \\ Engineering, Konya, Turkey;
}

*Corresponding author: Çiğdem Çiftçi, e-mail: cigdemciftci@erbakan.edu.tr;

Received March 2019; Accepted April 2019; Published July 2019;

DOI: https://doi.org/10.31407/ijees9309

\begin{abstract}
The uncontrolled urbanization caused significant changes in urban environmental conditions due to increased buildup areas of cities, reduction the urban landscape, disruption of human-environment relations. The urban environments consist of two superimposed systems as being natural and human-made. Urban plans consist of both design and these urban environmental components. Especially planner's environmental perception is too important for setting of environmental quality. Therefore, urban environmental quality and human value became the two key concepts of visual environment assessment. Each of these components have differences to its own geological, morphological, climatic structure etc. physical characteristics and that coming from social, cultural and systematic properties. So urban and environmental planners are responsible for shaping the urban environment as well as human, urban and environmental health professionals. This paper will be analyzed the environmental perceptions of university students of urban planning about urban environment and nature related to human and nature relationships. It chose Konya as a sample area for being a central living space of many all of university students. NEP scale with sample $12 \%$ applied to the student of University of Necmettin Erbakan's City and Regional Planning.
\end{abstract}

Key words: New Ecological Paradigm Scale (NEP), Environmental perception, Urban environment identity, Konya 